\title{
RESOLVING PROVINCIAL CROSS- BORDER DISPUTES UNDER THE CONSUMER PROTECTION ACT
}

\author{
Stephen Newman
}

B Com (Law) LLM (cum laude) LLM (International Trade Law) Diploma in Legislative Drafting Senior Lecturer, Department of Mercantile Law, Nelson Mandela University

Mark Tait $B$ Juris LLB MBL LLM LLD Associate Professor, Department of Mercantile Law, Nelson Mandela University

\section{SUMMARY}

This research sets out a practical enforcement problem which provincial consumer protection authorities are faced with under the Consumer Protection Act 68 of 2008. In the initial period after the Act became effective, many of the provincial authorities received complaints that involved the consumer and supplier being in different provinces. In terms of section 84 of the Act, which sets out jurisdictional limits of the provincial authorities, it appears that provincial authorities were only able to intervene in a dispute where the consumer and supplier are present in their province. The provincial authorities referred such cross-border disputes to the National Consumer Commission for resolution as the Commission has jurisdiction throughout the country. The Commission refused to deal with these individual disputes. This research sets out the sections of the Act, and other measures, which could potentially be used to try to resolve this situation.

\section{INTRODUCTION}

The Eastern Cape Department of Economic Development, Environmental Affairs and Tourism (DEDEAT), as part of a process to ensure the effective enforcement of consumer rights by the officials of the Eastern Cape Consumer Protection Authority, undertook a training programme to acquaint officials with the Consumer Protection Act. ${ }^{1}$ The Law Faculty of the Nelson Mandela University was approached to develop and run the training

68 of 2008; hereinafter "the CPA" or "Act". 
programme. $^{2}$

During the training, officials shared many of the consumers' complaints that they had encountered. ${ }^{3}$ In many instances, the complaints were quite simply a case of blatant fraud. Those complaints that were subject to the Act, gave insight into the need for consumer protection legislation, as the exploitation of consumers, particularly in the rural areas is quite frightening. One particular type of dispute that officials encountered, but had yet to resolve, was that of cross-border disputes; i.e., where the consumer is a resident in one province and the supplier in another.

This article addresses the attempts made by the Eastern Cape Consumer Protection Authority to resolve these cross-border disputes through the enforcement provisions in the CPA and the enforcement bodies created by the Act, notably the National Consumer Commission. ${ }^{4}$

\section{THE PROBLEM UNDERLYING CROSS-BORDER DISPUTES}

Due to the large rural population in the Eastern Cape, many family members work elsewhere in the country and on their return home, bring essential goods, which are not available locally or are cheaper in urban areas. When a problem arose with these goods, the consumers approached the Eastern Cape Consumer Protection Authority to assist them in resolving the dispute. The officials were unsure of how to resolve the dispute since the supplier was in another province and they had no jurisdiction in other provinces, despite the consumer being resident in their province. This is a consequence of consumer protection being a Schedule 4 function under the Constitution of the Republic of South Africa, which provides that both national and provincial government have concurrent legislative authority over this function. ${ }^{5}$ Thus, despite the CPA being national legislation, it cannot allow a provincial authority any cross-border jurisdiction and neither can a province's own legislation.

The provincial jurisdictional limitation makes it impossible for a provincial authority to resolve these cross-border disputes. ${ }^{6}$ The dispute seems to require a referral to the NCC. ${ }^{7}$ The Eastern Cape Consumer Protection Authority, as did a number of other provincial authorities who were experiencing similar problems, referred such disputes to the NCC for resolution, which resulted in the Commission being overrun with complaints from the provinces. ${ }^{8}$ The Commission never envisaged performing this type

2 The Law Faculty had previously assisted the Department of Economic Development, Environmental Affairs and Tourism when the CPA was officially launched within the province.

3 The authors were responsible for the training of these consumer protection officials in the Eastern Cape, both drafting the training programme and presenting it.

Established in terms of s 85(1) of the Act; hereinafter "the NCC" or "Commission". 108 of 1996.

S 84(b).

See s 99 for the enforcement functions of the Commission.

8 This information was obtained during various workshops held with the Eastern Cape provincial consumer protector during the training programme. 
of individual dispute resolution, believing their role to rather involve the overall policy implementation of consumer protection within the country. ${ }^{9}$

The response of the Commission to this deluge of complaints was to refer the matters back to the provinces, relying on section $84(\mathrm{~b})$ in support of this action. ${ }^{10}$

"84. A provincial consumer protection authority has jurisdiction within its province to -

(a) $\ldots$...

(b) facilitate the mediation or conciliation of a dispute arising in terms of this Act between or among persons resident, or carrying on business exclusively within that province;"

As can be seen, section 84(b) does not give the Commission any power to refer a dispute back to a provincial authority, but rather outlines the jurisdiction of a provincial consumer protection authority to facilitate the mediation or conciliation of a dispute between or among person's resident, or carrying on business exclusively within their province.

The difficulty that the Eastern Cape Consumer Protection Authority faced with this action by the NCC is evident from the following two phrases in the paragraph, "between or among persons resident within the province" and "carrying on business exclusively within that province". The former presented no difficulty as the provincial authority had jurisdiction over the consumer since the consumers were resident within the Eastern Cape. However, the suppliers were not carrying on business "exclusively" within the province, or at all. The Eastern Cape Consumer Protection Authority contended to the NCC that they could not mediate with the suppliers in these disputes, as they were either, not carrying on business exclusively within the Eastern Cape province, or at all. Therefore, the cross-border dispute must fall under the jurisdiction of the Commission, since they are the only body, in terms of the CPA, which has national jurisdiction. ${ }^{11}$

The response from the NCC was to decline responsibility for resolving the dispute, stating that, in terms of section 99(a):

"The Commission is responsible to enforce this Act by -

(a) promoting informal resolution of any dispute arising in terms of this Act between a consumer and a supplier, but is not responsible to intervene in or directly adjudicate any such dispute;"

The NCC contended that these were individual disputes and it was not responsible to intervene. ${ }^{12}$ This ended the matter in the eyes of the NCC, but not for the officials or consumers who were now without any obvious means to resolve the dispute, especially as the industry ombud had not yet been created. Officials were now at a loss as to which process they should utilise

9 Woker "Evaluating the Role of the National Consumer Commission in Ensuring that Consumers have Access to Redress" 2017 SA Merc LJ 6.

10 This explanation of the Commission was contained in emails sent to the Eastern Cape provincial consumer protection authority with respect to each dispute, which had been referred to the Commission.

11 Van Heerden "Section 84" in Naudé \& Eiselen (eds) Commentary on the CPA par 84-2.

12 See Van Heerden "Section 99" in Naudé \& Eiselen (eds) Commentary of the CPA par 99-5. 
or body they should approach for resolution. Even with the accreditation of industry codes and ombud schemes, ${ }^{13}$ this problem persists as the ombuds are only empowered to make recommendations. ${ }^{14}$ Should a supplier elect not to abide by a recommendation, the consumer will approach a provincial authority. Hence the problem which this article has identified; how does this type of dispute get resolved?

This uncertainty stems from a change in approach to the resolution of consumer disputes that developed as a result of the 2004 Draft Green Paper on the Consumer Policy Framework. ${ }^{15}$ Thus, before considering the attempts made to resolve the problem of cross-border disputes, it is useful to consider the approach South African consumer protection legislation has taken to dispute resolution, as this change has caused much of the confusion experienced by provincial authorities.

\section{A NEW APPROACH TO CONSUMER DISPUTE RESOLUTION}

The Draft Green Paper noted, "providing consumers with rights in law has little meaning if consumers cannot achieve quick and effective redress and if those rights are not effectively enforced" ${ }^{16}$ Consequently, much of the focus of current consumer legislation is on the protection of vulnerable and illiterate consumers. ${ }^{17}$ This is in light of the difficulties and challenges often faced by a consumer in obtaining justice and redress. ${ }^{18}$ Apart from the challenges due to South Africa's historical inequalities, other notable challenges include, approaching the traditional civil courts if suppliers will not resolve a complaint and the concurrent cost thereof and the lack of knowledge by consumers of the legal process. ${ }^{19}$ Instead of merely relying on the traditional civil courts, which are costly, often time-consuming, and geographically inaccessible for consumers, provision is made for alternative methods of dispute resolution, which aims to provide greater access to justice for a consumer. ${ }^{20}$

The National Credit $\mathrm{Act}^{21}$ (NCA) set the trend for a changing system of enforcement in South African law, which emphasised the necessity to ensure that effective redress and enforcement mechanisms must be in place and easily accessible for consumers. ${ }^{22}$ The NCA provides for disputes to be

13 The Motor Industry Ombud of South Africa (MIOSA) and Consumer Goods and Services Ombud (CGSO).

14 MIOSA clause 21.2.2 and CGSO code clause 9.1.3.

5 GN 1957 in GG 2677411 of 2004-09-09.

6 GN 1957 in GG 2677437 of 2004-09-09.

Van Eeden Consumer Protection Law in South Africa (2013) 451.

Ibid.

Woker "Consumer Protection and Alternative Dispute Resolution" 2016 SA Merc LJ 24.

Kelly-Louw Consumer Credit Regulation in South Africa (2012) 18 and 482; Otto and Otto The National Credit Act Explained 44.

2134 of 2005.

22 GN 1957 in GG 2677439 of 2004-09-09: "In order to enhance the enforcement capacity of consumer protection laws, foster coordination and give consumers access to effective redress mechanisms, it is therefore necessary to put in place a streamlined and more effective institutional framework for consumer protection". 
settled in an informal and inexpensive manner through a wide range of alternative dispute resolution mechanisms, including ombuds, consumer courts, other alternative dispute resolution agents and ultimately the National Credit Regulator (NCR) or National Consumer Tribunal (NCT). ${ }^{23}$

The CPA continued this trend and identifies the need to provide an accessible, consistent, harmonised, effective, and efficient system of redress for consumers. ${ }^{24}$ The Act establishes a dedicated national regulatory body similar to the NCR, namely the NCC and outlines its powers and functions. ${ }^{25}$ It provides for the referral of disputes to the NCT. ${ }^{26}$ Importantly, the Act formally recognises self-regulatory systems, in the form of industry codes, the establishment of industry ombuds, and other alternative dispute mechanisms as part of a broader regulatory framework. ${ }^{27}$ The CPA, in sections 69 and 70 establishes a similar procedure for dispute resolution to that of the NCA by prescribing the referral of disputes to ombuds, consumer courts or other alternative dispute resolution agents before, as a last resort, approaching a civil court. ${ }^{28}$

Yet, despite the number of new dispute resolution processes and bodies referred to in section 69 and 70 of the Act, provincial consumer protection authorities are not one of the bodies listed as an option to which a dispute may be referred. It is only in section 83 , which refers to the co-operative exercise of concurrent jurisdiction and section 84, which outlines the jurisdiction that these provincial authorities have within their province that gives any indication as to the role and function that they could fulfil. This reflects the fact that the CPA is limited in its ability to regulate provinces as consumer protection is a concurrent function of national and provincial government. The CPA thus envisages that provinces will align their consumer protection policy and legislation to the new rights-based system and give effect to the rights contained in the CPA through enforcement by provincial consumer protection authorities and courts. ${ }^{29}$

However, provincial consumer protection authorities quickly realised that this new dispute resolution mechanism did not provide a ready solution in

23 Kelly-Louw Consumer Credit Regulation in South Africa 482.

24 S 3(1)(h).

25 S 85(1).

26 The National Consumer Tribunal is established by section 26 of the National Credit Act and is defined as such body in section 1 of the CPA.

27 S 82 and 70 respectively; Van Eeden Consumer Protection Law in South Africa 388.

28 S 69(d): "A person contemplated in section 4(1) may seek to enforce any right in terms of this Act or in terms of a transaction or agreement, or otherwise resolve any dispute with a supplier, by - approaching a court with jurisdiction over the matter, if all other remedies available to that person in terms of national legislation have been exhausted."

29 Some provinces have opted to repeal their existing legislation and have promulgated new legislation such as KwaZulu-Natal Consumer Protection Act 04, 2013 in PG 02 of 2014-0213; Northern Cape Consumer Protection Act 01, 2012 in PG 1584 of 2012-03-28; Limpopo Consumer Protection Act 68, 2015 in PG 2734 of 2016-07-22; Eastern Cape Consumer Protection Bill, 2016 in PG 3618 of 2016-03-14; Gauteng Consumer Protection Bill in PG 179 of 2018-07-04. Others have simply amended their existing legislation such as North West Consumer Affairs (Unfair Business Practices) Amendment Bill, 2012 in PG 7068 of 2012-12-21. The remainder have simply retained their existing Consumer Affairs (Unfair Business Practices) Act and the Authorities and Tribunals operate in terms of this legislation to enforce the CPA rights; Woker 2016 SA Merc LJ 43. 
the case of a cross-border dispute and the purpose of the Act of providing an accessible, consistent, harmonised, effective and efficient system of redress for consumers was not easily achieved, if at all.

\section{POSSIBLE SOLUTIONS TO RESOLVE THE PROBLEM}

\section{Referral to and/or collaboration protocols with the NCC}

The provincial consumer protection authorities considered referring the disputes to the Commission under section 84(d) which allows a provincial authority to request the Commission to initiate a complaint in respect of any apparent prohibited conduct or offence in terms of this Act arising within that province. In many instances, the "offence" related to the supply of defective goods. This being a breach of a consumer's right to goods that are in good working order and free of any defects, arises at the time of the sale. ${ }^{30}$ While the provincial authority had jurisdiction over the resident consumer and the complaint had been lodged within their jurisdiction, the offence arose at the time of the sale, which occurred in another province. Thus the provincial authorities could not refer the matter to the Commission as the prohibited conduct or an offence arose in the other province.

Section 97 is another possible avenue which the provincial consumer protection authorities considered exploring in trying to resolve the crossborder complaint. Section 97(1)(a)(ii) allows the NCC to liaise with provincial consumer protection authorities on a specific complaint or investigation. Van Heerden points out that this section is likely an attempt to bridge the gap that exists between regulatory authorities. ${ }^{31}$ This section does not necessarily promote individual dispute resolution by the NCC but probably envisages that the relevant provincial consumer protection authority will provide information to the NCC in connection with an ongoing investigation by the Commission. The complaint may have arisen in that particular province, perhaps having been referred by the provincial consumer protection authorities under section 84(d). Alternatively, a national supplier may be carrying on business within the province and the Commission may require information on a specific complaint or investigation as part of a national investigation into similar complaints against the same supplier, which have arisen in another province.

The NCC is in the process of drafting a referral and collaboration protocol to regulate their relationship with, amongst others, the provincial consumer protection authorities. The introduction identifies one aim of the document which would appear to support the above interpretation that the provincial authority would support the NCC in its investigation and resolution of the complaint: $^{32}$

\section{S 55(2)(b).}

Van Heerden "Section 97" in Naudé \& Eiselen (eds) Commentary on the CPA par 97-2.

32 Referral and Collaboration Protocol NCC/Provinces and Regulators (1 April 2014) 2. 
"The Referral and Cooperation Protocols thereof serve to create a platform in terms of which issues of consumer protection are dealt with concurrently and jointly by the NCC, Provincial Authorities, Regulatory Authorities and accredited Ombudsmen Schemes in the spirit of co-operative governance within the ambit of Chapter 3 of the Constitution and sections 95 and 97 of the Consumer Protection Act read with sections ...;...;...;.; of the National Credit Act, respectively. (sic)"

The NCC thus acknowledges the possible need for collaboration with provincial authorities in the investigation and resolution of a dispute. Further reinforcing the idea of collaboration, the document quotes the Constitution ${ }^{33}$ when it states that all spheres of government and all organs of state, including the NCC, Provincial Authorities, Regulatory Authorities and Accredited Ombudsmen Schemes must co-operate with one another in mutual trust and good faith by fostering friendly relations and assisting and supporting one another. ${ }^{34}$

This document seemed to offer a possible solution for provincial consumer protection authorities in dealing with cross-border disputes. However, any hope that this document would assist in the resolution of cross-border disputes was dispelled as the draft document goes on to paraphrase section 99(a). The document, in the background section, states that: ${ }^{35}$

"Provincial authorities have jurisdiction to facilitate the mediation or conciliation of a dispute arising in terms of this Act between a supplier and consumer, which is something the NCC does not have jurisdiction to do".

From the above extract, it can be seen that the NCC emphatically states that they do not have the jurisdiction to involve themselves in the mediation and conciliation of disputes. However, it must be noted that the important jurisdictional restrictions identified in section 84(b), that of "persons resident" and "carrying on business exclusively within that province" are absent from this background statement in the document. As to why the NCC omits this restriction in the document, one can only speculate. Perhaps the reason is that this provincial jurisdictional limitation would create a problem for any referral protocol between the NCC and provincial authorities, as section 84 (b), which the NCC is relying on, clearly limits the ability of a province to deal with a dispute unless it complies with the jurisdictional requirement.

It must also be noted that section 84(b) does not make provision for the referral, by the NCC, of a dispute back to a province. It would seem that the NCC is merely directing the provincial authorities' attention to this section of the CPA, intending to indicate to the provincial authorities that they should fulfil their function and not pass on the dispute to the NCC.

The document immediately thereafter states that section 69(c)(ii) of the Act affords consumers the right to approach a provincial court of the province where such court exists. ${ }^{36}$ Again, the document does not include the limiting aspect of this section namely, "subject to the law establishing or

\footnotetext{
S 41(1)(h); Constitution of the Republic of South Africa, 1996.

Referral and Collaboration Protocol NCC/Provinces and Regulators (1 April 2014) 2.

Referral and Collaboration Protocol NCC/Provinces and Regulators 3.

3.
} 
governing that consumer court". Any provincial legislation establishing the consumer court can only provide the court with jurisdiction within its own province. This accords with section 84(c) of the CPA which allows a provincial authority to refer a dispute contemplated in section $84(\mathrm{~b})$ to the provincial consumer court within that province. The reference to section 84(b) is key as this imposes the jurisdictional limitation of "carrying on business exclusively within the province". Clearly, in the case of a crossborder dispute, referral to a provincial consumer court in terms of section 69 (c)(ii) as suggested by the protocol is not an option.

Another aspect which provincial authorities considered was the question of what actually constitutes carrying on business, "exclusively within the Province"? A national chain such as Shoprite, Checkers or Pick 'n Pay will never fall under the jurisdiction of a provincial authority as they carry on business in many different provinces and will be subject to the NCC. ${ }^{37}$ The majority of consumers in South Africa make use of these national chains and if the NCC will not intervene directly in an individual dispute, consumers may be left without any redress. Potentially, one could look at the particular type of business model used by a business. For example, Spar has an individual ownership business model. These individually owned stores could then be considered to be carrying on business exclusively within the province. This would be so in the case of a franchise as well. Section 2(1) states that the Act must be interpreted in a manner that gives effect to the purposes set out in section 3. Two of the purposes of the Act are to promote and advance the social and economic welfare of consumers in South Africa by: ${ }^{38}$

"(g) providing for a consistent, accessible and efficient system of consensual resolution of disputes arising from consumer transactions; and

(h) providing for an accessible, consistent, harmonised, effective and efficient system of redress for consumers."

If a court were to adopt an interpretation of the requirement of carrying on business exclusively within the province, which considers that franchises or independently owned shops are carrying on business exclusively within the province, it would benefit consumers by granting jurisdiction to the provincial authority where the consumer is resident. This would give effect to the purposes of providing accessible consensual dispute resolution and an accessible system of redress.

The possibility of utilising section 71 of the Act was also explored. Section 71(1) allows "any person" to file a complaint with the Commission alleging a person has acted in a manner inconsistent with the Act. "Person" is defined in section 1 as to include a jurist person and a "juristic person" is defined to include a body corporate, partnership or association or a trust. It is of interest to note that the Northern Cape Consumer Protection Act $^{4}{ }^{4}$ specifically makes provision that the authority is a juristic person, while the Kwazulu-Natal Cape

37 Van Heerden "Section 84" in Naudé and Eiselen (eds) Commentary on the CPA par 84-2.

38 S $3(1)$

39 There is an anomaly in this subsection as it refers to $s 69(1)(c)(i i)$ and (2)(b). This is a reference to the Draft Consumer Protection Bill and these paragraphs were incorporated into s 70 in the CPA; Van Heerden "Section 71" in Naudé and Eiselen (eds) Commentary on the CPA par 71-3.

$40 \mathrm{~S} 4(2)(\mathrm{a})$. 
Consumer Protection $\mathrm{Act}^{41}$ states that the authority is not a juristic person. The remaining provinces' legislation is silent on this aspect. Thus, the Northern Cape consumer protection authority would clearly fall within the category of "any person". For the other provincial consumer protection authorities the situation is not so clear-cut, however, the phrase "any person" could be interpreted widely to include such provincial authorities. This would again be in keeping with the above-mentioned purposes of the Act.

Furthermore, if there is any doubt as to the filing of a complaint by a provincial authority under section 71(1), section 71(2)(b)(i) is available to provincial consumer protection authorities. This section makes provision for the Commission to initiate a complaint concerning alleged prohibited conduct at the request of a provincial consumer protection authority:

"(2) The Commission may directly initiate a complaint concerning any alleged prohibited conduct on its own motion, or -

(a) $\ldots$...

(b) on the request of -

(i) a provincial consumer protection authority;"

In the current situation, the provincial consumer protection authorities were definitely requesting the Commission to initiate a complaint in terms of section 71(2)(b)(i). The section, however, makes use of the word "may", giving the Commission discretion to initiate a complaint. The provincial authorities were dependent on the Commission deciding to initiate the complaint on their behalf. The Commission refused to do so, not on the basis that the complaints were not covered under the Act, but by reference to section 99(a) as the Commission considered these "individual disputes". 42 The consequence of this refusal by the Commission was that the provincial authorities had to explore some other avenue to try and assist the consumers.

Another possibility arises in section 83(4):

"At the request of the relevant MEC of a province, or a provincial consumer protection authority, the Commission may engage with that provincial consumer protection authority in co-operative activities to detect and suppress prohibited conduct or offences in terms of this Act, if there are reasonable grounds to believe that any such conduct or offences may be occurring within the province, or across its provincial boundaries (author's own emphasis)."

This section clearly envisages the likelihood that prohibited conduct or offences may occur across provincial boundaries with a consumer in one province and the supplier in another. In such instances, provincial authorities, who not have jurisdiction to resolve the dispute in terms of section 84(b), will then be able to request their relevant MEC to approach the Commission for assistance in dealing with the prohibited conduct or offence or may do so themselves directly. ${ }^{43}$ It would seem that this section

$41 \mathrm{~S} 5(2)$

42 This explanation of the Commission was contained in emails sent to the various provincial consumer protection authorities with respect to each dispute that had been referred to the Commission.

43 Van Heerden "Section 83" in Naudé and Eiselen (eds) Commentary of the CPA par 83-5. 
deals with the exact complaint the provincial consumer protection authorities were dealing with.

Similarly, section 83(5) could have been utilised as it states:

"At the direction of the Minister, the Commission must engage with any relevant provincial consumer protection authority in co-operative activities to detect and suppress prohibited conduct or offences in terms of this Act, occurring within the province or across its provincial boundaries."

This intervention would come from the Minister of Trade and Industry, probably after requests from the relevant provincial MEC's.

Equally, section 83(1) would be applicable which provides:

"As contemplated in section 41(2) of the Constitution, the Minister must consult with the responsible Member of any relevant provincial Executive Council -

(a) to co-ordinate and harmonise the functions to be performed by theCommission and one or more provincial consumer protection authorities; and

(b) when necessary, to facilitate the settlement of any dispute between the Commission and one or more provincial consumer protection authorities,"

Of particular relevance to this would be section $83(1)(b)$ as there is clearly a dispute between the two bodies and the Minister could then make a determination to settle the dispute, that being whether the Commission should deal with the cross-border individual disputes. The functions of the Commission and provincial consumer protection authorities could then also be harmonised at executive level, under which both authorities reside, in terms of section $83(1)(a) .{ }^{44}$ Section $83(2)(b)$ further endorses this, which states:

"If this Act contemplates that the respective provincial consumer protection authorities will perform a particular function within their respective provinces, and -

(a) $\ldots$

(b) the Minister concludes on reasonable grounds that the provincial consumer protection authority within a particular province is unable to perform that function effectively, the Minister must consult with the responsible MEC of that province to determine the steps to be taken to ensure the fulfilment of that statutory obligation.

In this instance, the provincial consumer protection authorities cannot perform the consumer protection function effectively because they have no jurisdiction across their provincial borders. The Minister could determine the steps to be taken to ensure fulfilment of the statutory obligation, which ideally would be that the Commission deal with such cross-border disputes. This would also give effect to the purposes of the Act of providing accessible consensual dispute resolution and an accessible system of redress. ${ }^{45}$

44 See also Van Heerden "Section 83" in Naudé and Eiselen (eds) Commentary of the CPA par 83-4.

$45 \quad \mathrm{~S} 3(1)(\mathrm{g})$ and $(\mathrm{h})$. 
However, in the current attempts by the provincial authorities to resolve the complaints, section 83 was not considered. Ultimately, the presence of section 99(a) in the CPA provided the Commission with the authority it needed to remain a disinterested party to a cross-border dispute, as the complaints were individual disputes, which the Commission would not intervene directly in.

\section{Collaboration/referral protocol between provinces}

After the rejection by the Commission of the requests for assistance by the provincial authorities, an option available to the Eastern Cape Consumer Protection Authority was to attempt to facilitate negotiations between the consumer and supplier in an attempt resolve the dispute. Section 84(b) does make provision for mediation or conciliation of a dispute by an authority, however, there is the jurisdictional restriction that the supplier must be carrying on business exclusively within the province. Nothing in section 84 makes provision for a cross-border dispute, which is understandable, as consumer protection is a functional area of concurrent jurisdiction, to be regulated and in terms of both national and provincial legislation and performed by both national and provincial bodies. Not even national legislation, in the form of the CPA, can provide that one province will have authority or jurisdiction in another province. Suppliers simply refused to negotiate with officials when they were informed that it was a different provincial authority. ${ }^{46}$ Whether this was because of knowledge of the jurisdictional limitation of the Act or that the suppliers simply believed that someone from a different province would have no jurisdiction over them was uncertain.

Ultimately, all the Eastern Cape provincial consumer protection authority could do was to request the provincial authority, where the supplier was carrying on business, to intercede on their consumer's behalf. There being no agreement or protocol between provinces to regulate this situation, the relevant provincial authority could decide whether it would assist or not. In practice, this assistance was seldom forthcoming as the provincial authorities were already dealing with a large number of their own complaints and had limited resources available to them.

Provincial consumer protection authorities were aware that scarce resources could be better spent assisting their own consumers by resolving disputes over which they did have jurisdiction rather than those from other provinces. The reality was that the consumers were not within their jurisdiction since they were not resident within the province and there was little that they could do anyway, especially as the suppliers invariably were not co-operative in negotiations. At best, the provincial authority where the supplier is carrying on business could be requested to refer the dispute to the Commission in terms of section 84(d). However, the Commission would not deal with this complaint as it is an individual dispute.

46 Information provided by the Eastern Cape Consumer Protector during interviews and discussions held to consider ways of resolving the complaints. 
Provinces did explore the possibility that the provincial consumer protection authorities enter into collaboration agreements in order to resolve cross-border complaints. This would not resolve the issue of cross-border disputes as each provincial consumer protection authority is still bound by the jurisdictional limit of section 84. The Gauteng Province Consumer Protection Policy identifies that provinces need to co-operate in sharing information on cross-border disputes. ${ }^{47}$ This would allow provincial consumer protection authorities to investigate the conduct of a supplier, based on the information of alleged prohibited conduct provided by another provincial authority, the assumption being that the resident consumers would also be subject to such prohibited conduct.

\section{Referral to an Industry Ombud ${ }^{48}$}

It would appear from the wording of sections 69 and 70, in particular, section 69 (c)(i), that in the majority of instances, referral to an industry ombud will be the first step in the resolution of a complaint by a consumer. ${ }^{49}$ Dispute resolution through ombud schemes is considered more accessible to consumers, as the consumer does not bear the cost of expensive litigation. Section 82 provides for the establishment of industry codes and the Minister may prescribe an industry code for a particular industry on the recommendation of the National Consumer Commission. ${ }^{50}$ Section 82(6) allows for the accreditation of an industry ombud if the code allows for an ADR scheme, which the Commission considers sufficient.

To date, the Minister has accredited only two industry codes namely, the South African Automotive Industry (SAAI) Code of Conduct and the Consumer Goods and Services Industry (CGSI) Code of Conduct. ${ }^{52}$ Both the codes set out a structure of alternative dispute resolution and thus qualify for an accredited industry ombud namely, the Motor Industry Ombud of South Africa (MIOSA) ${ }^{53}$ and the Consumer Goods and Services Ombud (CGSO). ${ }^{54}$ This allows for self-regulation by a particular industry and a consumer is now able to refer a dispute regarding products or services of these two industries to the ombud for resolution.

47 PN 758 in PG 125 of 2017-05-31 17.

48 At the time that these cross-border disputes arose, the two recognised ombud schemes had not yet come into existence. However, to deal with the problem completely this note considers the referral of the dispute to an ombud for resolution.

49 Van Heerden is of the opinion that section 69 creates a hierarchy for dispute resolution forums. See Van Heerden "Section 69" in Naudé and Eiselen (eds) Commentary of the CPA par 69-2.

$50 \mathrm{~S} 82(2)$.

51 The Minister of Trade and Industry has accredited two industry codes namely, the South African Automotive Industry Code of Conduct and the Consumer Goods and Services Industry Code of Conduct. Both the codes set out a structure of alternative dispute resolution and thus qualify for an accredited industry ombud namely, the Motor Industry Ombud of South Africa (GN 817 in GG 38071 of 2014-10-17) and the Consumer Goods and Services Ombud (GN 217 in GG 38637 of 2015-03-30.)

52 Melville and Yeats "Section 82" in Naudé and Eiselen (eds) Commentary of the CPA par 82-6.

53 GN 817 in GG 38071 of 2014-10-17.

54 GN 217 in GG 38637 of 2015-03-30. 
A consumer is now able to refer a dispute regarding products or services of these two industries to the ombud for resolution. ${ }^{55}$ The industry code will then determine the manner of lodging the complaint and the process of dealing with it. The ombuds' offices are situated in Johannesburg, thus consumers outside this area will have little or no direct access to these ombuds. ${ }^{56}$ The fact that the two ombud schemes have websites may ameliorate this situation and consumers are able to submit a complaint electronically, making use of the links on the websites. ${ }^{57}$

However, South Africa has a large rural population, which represents the most vulnerable of consumers. They will have no access to the offices of ombuds and, in most instances, have no internet access so cannot complete online complaints. This may well result in a similar problem to expensive litigation, that due to monetary constraints, a consumer cannot access ombud schemes. ${ }^{58}$ Furthermore, section 84 of the CPA, which sets out the jurisdiction of a provincial consumer protection authority, does not include liaising with a relevant ombud as a function of a provincial consumer protection authority. This is to be expected as such a provision would be overstepping the legislative competence of national legislative bodies. As a concurrent function, this function would have to be provided for in provincial legislation. The various provincial Consumer Protection Acts do not explicitly mention liaising with a relevant ombud as part of their function, but this would make sense in the execution of their function of assisting consumers in resolving complaints.

Another potential problem is that consumers may not know which ombud or regulatory body to approach to resolve a dispute. Section 69 indicates that one should approach an applicable ombud with jurisdiction if a supplier is subject to such jurisdiction, alternately an accredited industry ombud. ${ }^{59}$ This could result in a consumer being sent from one regulatory body to another if they are unsure of which ombud has jurisdiction. ${ }^{60}$ The Act does not deal with the inter-relationship between the various regulatory bodies.

Furthermore, the industry ombud only has the authority to make a recommendation for consent between the parties and neither of the codes makes this recommendation binding. ${ }^{61}$ Consequently, a supplier can simply refuse to participate in the process or simply ignore the recommendation if it is in the consumer's favour. ${ }^{62}$ Section 70(2) caters for this situation and sets out the procedure to follow. The ombud may terminate the proceedings if there is no reasonable prospect of success and the consumer may thereafter file a complaint with the Commission. Yet again, the consumer is

\footnotetext{
S 69(c)(i) and 70(1)(b); Melville and Yeats "Section 82" in Naudé and Eiselen (eds) Commentary of the CPA par 82-6. 
faced with the prospect that the Commission will not deal with the individual dispute. ${ }^{63}$

A further threat to the CGSO has recently arisen as suppliers are now refusing to register and pay towards the funding of the scheme. ${ }^{64}$ This places the very existence of the CGSO at risk and would be a disastrous consequence for consumers given the refusal of the Commission to handle individual disputes. ${ }^{65}$

\section{Referral to the NCT}

The Act makes provision for a referral by a consumer to the National Consumer Tribunal, established in terms of the NCA. ${ }^{66}$ The consumer may only do so upon the issuing of a notice of non-referral by the Commission and with the leave of the Tribunal. ${ }^{67}$ Alternately, the issuance of a notice of non-referral by the Commission may allow the complainant to submit the matter to a provincial consumer court. ${ }^{68}$ However, this may only be done in the province where the complainant resides or in which the respondent has its principal place of business. In the case of a cross-border dispute, a provincial consumer court will not have jurisdiction to hear such a referral due to the jurisdictional limit of section $84(b)$.

The Act sets out the grounds on which the Commission may issue a notice of non-referral. Section 72(1) states: ${ }^{69}$

"Upon initiating or receiving a complaint in terms of this Act, the Commission may -

(a) issue a notice of non-referral to the complainant in the prescribed form, if the complaint -

(i) appears to be frivolous or vexatious;

(ii) does not allege any facts which, if true, would constitute grounds for a remedy under this Act; or

(iii) is prevented, in terms of section 116, from being referred to the Tribunal;"

It should be noted that these grounds all refer to an instance where the facts of a complaint do not indicate that there is any basis for the complaint, or, in terms of section 116, the claim has prescribed. ${ }^{70}$ This is not necessarily the case in any of the cross-border complaints so it will be impossible to refer the dispute to the NCT through the issuance of a letter of non-referral by the Commission. Thus, where the consumer does have a legitimate complaint that they have referred to the Commission, the

63 Melville and Yeats "Section 82" in Naudé and Eiselen (eds) Commentary of the CPA par 82-13.

64 Knowler "Future of Consumer Goods and Services Ombud at Risk" (2017-05-10 http://www.bizcommunity.com/Article/196/307/161572.html (accessed 2017-08-17).

$65 \mathrm{Ibid}$

66 S 69(a).

67 S 75(1)(b).

68 S 75(1)(a)

69 S 72(1)(a)(i)-(iii).

70 See also Van Heerden "Section 72" in Naudé and Eiselen (eds) Commentary of the CPA par 72-2. 
Commission may not issue a letter of non-referral and the dispute must be resolved through another process.

The Act, in sections 72 and 73 , sets out the various bodies to which the Commission may refer the consumer to in an attempt to resolve the dispute. ${ }^{71}$ However, the consumer may already have approached the bodies referred to in the sections in an attempt to resolve the dispute or may not be able to. For example, section 72 allows for the referral of the complaint to an alternative dispute resolution agent. ${ }^{72}$ This ADR agent includes an industry ombud or ombud with jurisdiction. ${ }^{73}$ A consumer, in all likelihood, would have first lodged the complaint with an ombud, the outcome of which may have been unsatisfactory, leading to the filing of the complaint with the Commission in terms of section 71(1). Clearly, it would be nonsensical to refer the dispute back to the ombud that has already considered the dispute.

Section 73 allows for the referral by Commission of a complaint to a provincial court in which the supplier has its principal place of business. ${ }^{74}$ However, such referral will be meaningless if the consumer is not also resident in that province because of the jurisdictional limitation of provincial consumer courts contained in section 84, which requires the consumer to be resident in the province. ${ }^{75}$ Because of the cross-border nature of the complaints, it will be pointless for the Commission to make such a referral, as the provincial consumer courts will have no jurisdiction over the dispute.

\section{Legislative amendments}

One of the functions of the Commission is to identify any national or provincial legislation that affects the welfare of consumers and is inconsistent with the purposes of the Act. ${ }^{76}$ It is unlikely, that this function would be of any assistance in cross-border disputes. Firstly, the Commission, through the Minister, would not be able to make any recommendation with respect to a change in provincial legislation due to consumer protection being a Schedule 4 function under the Constitution and the provinces have legislative sovereignty in this respect. Secondly, it is impossible for provincial legislation to have any provincial cross-border effect, as provinces are only able to legislate for their own province.

The most effective solution would be to amend the CPA in order to achieve the purpose of the Act of providing for an accessible, consistent, harmonised, effective, and efficient system of redress for consumers. The Commission may make a recommendation to amend the Act to allow it to deal with these types of individual, cross-border disputes. However, this would mean that the Commission would have to undertake individual dispute resolution, which would run contrary to its own standpoint, adopted in 2012,

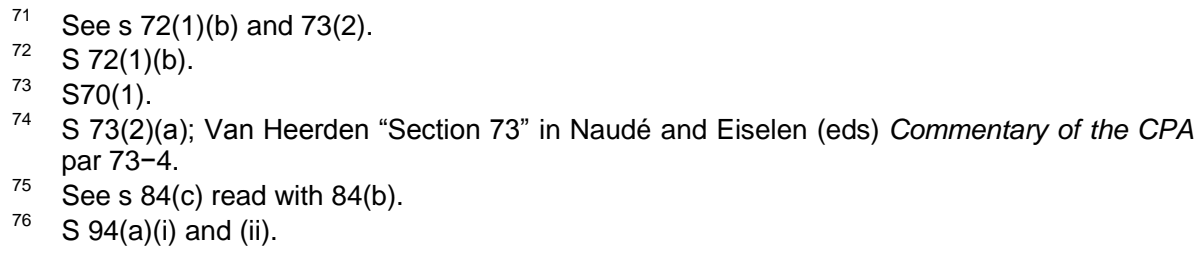


to include other forums in the dispute resolution process and no longer investigate individual complaints but focus rather on issues of policy. ${ }^{77}$

\section{Other measures}

An option would be to apply to the High Court, by way of an ex parte application, for a declaratory order on the functions of the Commission, in particular, in the case of cross-border disputes. ${ }^{78}$ Any of the provincial consumer protection authorities could do this, as an interested party. The order would hinge on the interpretation of section 99(a), that the Commission does not have to involve itself in individual disputes. Emphasis would have to be placed on the purpose of the Act of providing or an accessible, consistent, harmonised, effective, and efficient system of redress for consumers. ${ }^{79}$ In the case of cross-border disputes, consumers do not currently have access to an effective system of redress due to the Commission's refusal to intercede in individual disputes.

Another option would be to make a submission to the Public Protector. ${ }^{80}$ The Public Protector has the power, as regulated by national legislation: to investigate any conduct in state affairs, or in the public administration in any sphere of government, that is alleged or suspected to be improper or to result in any impropriety or prejudice. ${ }^{81}$ Any person may report a matter to the Public Protector for investigation, setting out the nature of the matter and the grounds upon which they feel the matter should be investigated by the Public Protector.

The provincial consumer protection authorities could request such an investigation on the basis that the omission by the National Consumer Commission to resolve the cross-border disputes, would lead to improper prejudice to consumers. ${ }^{83}$ The Public Protector would then conduct a preliminary investigation of the complaint made by the provincial authorities to determine its merits and decide how the matter should be dealt with. ${ }^{84}$

If the Public Protector decided to investigate the complaint further, it could then request affidavits or an explanation on the matter from all concerned parties. ${ }^{85}$ Thereafter, the Public Protector could publish the findings of the investigation and make a recommendation. ${ }^{86}$ Should the Public Protector find that the Commission is acting to the prejudice of consumers by not dealing with cross-border disputes, it could recommend that the Commission do so in the interests of achieving the purpose of the Act of providing for an

77 Woker 2017 SA Merc LJ 6.

78 Rule 6(1) of the Uniform Rules of Court as enacted in terms pf s 30 of the Superior Courts Act 10, 2013.

79 S 3(1)(h).

80 The Public Protector is appointed by the State President in terms of $s 193$ of the Constitution.

S 182(1) of the Constitution.

82 S 6(1)(a) of the Public Protector Act 23, 1994

83 S 6(4)(a)(v) of the Public Protector Act 23, 1994.

84 S 7(1)(a) of the Public Protector Act 23, 1994.

85 S 7(4)(a) and (b) of the Public Protector Act 23, 1994.

86 S 8(1) of the Public Protector Act 23, 1994. 
accessible, consistent, harmonised, effective, and efficient system of redress for consumers. ${ }^{87}$

\section{$5 \quad$ CONCLUSION}

Provincial consumer protection authorities are at a loss as to how to resolve cross-border disputes. Clearly, they have no jurisdiction to resolve these disputes and the Act indicates the NCC as the responsible body. Yet the Commission relies on section 99(a) and does not involve itself in individual disputes. The extent of this problem is evident from the fact that it has specifically been identified as a concern in the 2017 Gauteng Consumer Protection Policy. ${ }^{88}$

The consumer has a limited choice of approaching the NCT, but only upon the issuance of a letter of non-referral by the Commission. If such a letter is issued, it implies that there is no basis for the complaint. The Commission may issue such a letter in the case of cross-border disputes, but this means consumers are bound to a forum that is distant from them and have little assistance as provincial authorities cannot represent them.

Industry ombuds would seem to be the most likely route for consumers to follow to resolve the dispute. Yet, the CGSO and MIOSA may only make a recommendation so a supplier may simply ignore this, leaving the consumer in exactly the same position as when they approached a provincial authority. In addition, the CGSO is under threat of closure due to non-participation by suppliers.

Consumers could follow the traditional approach of resolving a contractual dispute by referring the matter to a court. However, this is not what the Act envisages and specifically tries to avoid this by placing it as a last resort in the list of available bodies in section 69. Traditional courts are also often inaccessible for the majority of consumers for the reason given in this note and as most consumer contracts are for relatively small values. This would also not give effect to the purposes of the Act of providing for a consistent, accessible, and efficient system of consensual resolution of disputes arising from consumer transactions and providing for an accessible, consistent, harmonised, effective and efficient system of redress for consumers.

It would appear, at this stage that the only way that this can be resolved would be to amend the CPA specifically to bring this type of dispute within the jurisdiction of the NCC. This would not be ideal as the Commission is already overstretched. The resolution of this dispute relies on the complete functioning of all bodies within the system, which does not seem to be happening at this stage. Currently, the advice for consumers would be; "Local is Lekker" buy in your home province!

\footnotetext{
S 3(1)(h).

PN 758 in $P G 125$ 2017-05-31 17.
} 